\title{
Societal Impacts of a Rapidly Changing Arctic
}

\author{
Kathrin Stephen ${ }^{1}$ \\ Published online: 3 July 2018 \\ (C) The Author(s) 2018
}

\begin{abstract}
This review article makes six observations about the current body of research on the societal impacts of a changing Arctic. First, climate change and globalisation are the dominant drivers of societal impacts in the Arctic. Second, many contributions focus on the impacts in concrete sectors of society, often from an opportunities-and-risks perspective, which tends to blur the boundary to more policy-oriented work. Third, the mantra of the sustainable development of the Arctic or Arctic sustainability pervades considerations of Arctic societal impacts. Fourth, societal and environment change in the Arctic is increasingly analysed using the image of the Global Arctic, highlighting the inextricable linkages between Arctic and global processes and systems and thus the entangled fate of the North and the entire globe. Fifth, an increasing number of actors is seen as being involved in societal and environmental transformations in the Arctic, often conveyed through the (often ill-defined) stakeholder concept. Sixth, Arctic indigenous peoples are depicted as the group most vulnerable to the societal impacts of a changing Arctic, but are increasingly the subject of research in the form of rights-holders and active participants in governance, law, politics, and research. Challenges for future research include achieving greater clarity and reflexivity around key concepts, and de-essentialising the Arctic via the use of comparative methods on cases both within and beyond the Arctic.
\end{abstract}

Keywords Arctic $\cdot$ Impacts $\cdot$ Society $\cdot$ Climate change $\cdot$ Globalisation · Oil and gas · Shipping · Fisheries · Tourism · Agriculture $\cdot$ Tourism $\cdot$ Community viability $\cdot$ Power relations $\cdot$ Indigenous peoples $\cdot$ Sustainable development $\cdot$ Sustainability $\cdot$ Global Arctic

\section{The Ultimate Drivers of Arctic Change: Climate Change and Globalisation}

The Arctic consists of an ocean surrounded by the northern fringes of the Eurasian and North American landmasses. Its southern limits are defined variously as the Arctic Circle at $66^{\circ}$ northern latitude, the treeline, the July $10{ }^{\circ} \mathrm{C}$ isotherm ${ }^{1}$ or permafrost extent. But jurisdictional, administrative, and political lines are also used for delimiting the Arctic's southern boundaries, for example as in the Arctic Human Development Report [1, p. 17 f.]. Ultimately, there is no single given 'Arctic' area, but several definitions of a region that has historically seen many, socially constructed, demarcations of its

${ }^{1}$ This is the line north of which the average temperature does not reach above $10{ }^{\circ} \mathrm{C}$ during the month of July.

This article is part of the Topical Collection on Arctic Climate Change

Kathrin Stephen

kathrin.stephen@iass-potsdam.de

1 Institute for Advanced Sustainability Studies (IASS), Berliner Str. 130, 14467 Potsdam, Germany southern fringes [2]. Regions in this area are home to a highly diverse and often unique flora and fauna as well as to people, including indigenous groups, who have lived for a long time in, and adapted to, some of the most extreme climatic, weather, and daylight conditions on the planet [3, p. 4 f.]. Socioecological systems in Arctic regions are also highly vulnerable in light of the extreme conditions to which these relationships are adapted, including short growing seasons, long distances, low population densities, and few opportunities to replace or substitute food and other items necessary for survival and everyday life, especially in the polar barrens of the High Arctic. On the other hand, the Arctic is a highly diverse region with bustling cities like Tromsø, Reykjavik, and Rovaniemi, and has well-developed infrastructure, especially on the European side of the Arctic. Different geographic realities, demographic structures, political and legal systems, and images [4] of the Arctic as a region make for varying impacts of and responses to global change processes like climate change and globalisation in different Arctic areas [5, Ch. 2].

While change has been termed a normal state of affairs in the Arctic, the pace and extent of current ecological and societal transformations are unprecedented. They are also 
accompanied by a high level of uncertainty concerning the future guise of Arctic change and its mid- to long-term impacts $[5, p . i x ; 4]$. Climate change is seen as the most pervasive and powerful driver of change, with temperatures in the Arctic having risen twice as rapidly as the global average over the past 50 years (a phenomenon called Arctic Amplification). Predictions regarding Arctic climate change include a 4$5{ }^{\circ} \mathrm{C}$ increase above late twentieth century values before the middle of this century ${ }^{2}$; sea ice extent and thickness continuing on a long-term downward trend with the latter having decreased by $65 \%$ between 1975 and 2012; an ice-free Arctic Ocean in summer by the late 2030s, with likely effects such as accelerating climate change through the exposure of dark land and ocean surfaces that absorb more heat; the thawing of permafrost with effects on carbon storage and release in the Arctic; changing and more extreme weather patterns in mid-latitudes; altered ocean circulation due to increasing freshwater storage in the Arctic Ocean; and the melting of Arctic land-based ice - especially in Greenland - contributing up to $25 \mathrm{~cm}$ of sea-level rise by 2100 [6].

In addition to the numerous effects of climate change, rapid social and economic developments, such as migration, tourism, resource extraction, shifting political relations, geopolitics, and more generally the forces of globalisation, have far-reaching impacts on the Arctic's social, ecological, and socio-ecological systems [7-10]. From a historical point of view, the Arctic has been part of globalisation processes for a long time, for example in the form of economic integration and trade relationships during the fur trade and whale hunting days, which in some parts of the Arctic date back as far as the sixteenth century [11-16]. But the pace of globalisation and its impacts has increased in recent years, with the Arctic said to become relevant for global trade networks, resource supply chains [17, pp. 6-9], and increasingly embedded in information and communication systems [18, p. 402].

Other globalisation processes that are deemed relevant for Arctic transformations are political power transitions in the global order-especially the shift from a unipolar to a multipolar order - and the increasing attention of traditionally understood non-Arctic states towards the Arctic [19, 20]. The ever-increasing number and complexity of international organisations, legal agreements, and norms that relate to the Arctic is also increasingly scrutinised by Arctic researchers [21] especially concerning the marine Arctic [22-26]. The role of the (international) media in the presentation of climate change, and the framing of current and future Arctic narratives, is an interesting new field of research $[27,28]$. Finally, cultural globalisation in the

\footnotetext{
2 This assumes medium or high greenhouse gas concentration scenarios, but these increases could even occur in the situation of drastic near-term emission cuts because of a lock-in effect through past emissions and heat stored in the oceans [5, p. viii].
}

form of global, or predominantly western, cultural trends like certain consumption patterns, increasing usage of information technology, and emancipated orientations towards gender equality, participation, and protest cultures increasingly penetrate and socially and culturally transform Arctic societies [18, pp. 416-9; 29, p. 225].

The following sections highlight three categories of societal impacts of climate change and globalisation processes in the Arctic. These are (1) the impacts on specific societal sectors, (2) impacts on Arctic peoples and players, and (3) crosscutting themes of Arctic societal impacts, comprising the mantra of sustainable development and sustainability and the tale of the Global Arctic. For reasons of scope, this article focuses on the current English literature, but it deserves mentioning that there is a vast and growing literature on the topic in other languages as well. Moreover, the article predominantly, but not exclusively, reviews the literature of the past five years, and therefore reflects the large number of books and edited volumes on Arctic societal change that was published during this timeframe. A concluding section makes six observations about the state of current research, and suggests pathways for future research on the societal impacts of a changing Arctic.

\section{Impacts by Societal Sector}

Current literature often analyses the societal impacts of climate change and globalisation in concrete sectors of society. These range from the new supply of (especially marine) resources, additional transport and shipping routes, and fishery and agriculture opportunities. The Arctic has also been put in focus as a new and expanding tourism destination, with complex impacts on Arctic regions and concerns as to the sustainable conduct of such new activities for the local environment and Arctic people. The majority of analyses takes an on the one hand... on the other hand approach, which (perhaps unwittingly) highlights the possible 'opportunities' and 'benefits' of Arctic exploitation, in contrast to looming dangers and risks.

\section{Oil and Gas}

Among the societal transformations in focus in the recent literature are the possibly increasing accessibility and utilisation of resources in the Arctic, specifically of conventional oil and gas resources expected under the seabed of Arctic waters. Next to the assessment of the geological existence of such resources [30,31], contributions focus on further factors determining the (im)plausibility or (un)desirability of exploring and extracting Arctic resources, such as responsibilities and liabilities in terms of risk management and local benefit arrangements [22, Pt. 
IV; 32, 33], the (in)compatibility of Arctic oil and gas extraction with notions of sustainable development [34], the culturally detrimental effects of oil and gas development, for example through the removal and destruction of pasture land [35], national offshore regulations [22, Pt. II], the impact of international economic and political factors on Arctic oil and gas developments [36, 37], and how such factors play out in specific places like the Barents region [38]. Koivurova points out that the assessment of the (im)plausibility or (un)desirability of oil and gas endeavours in the Arctic is a learning process and thus subject to change [39].

\section{Shipping}

Existing research also scrutinises the opportunities to use new transport, especially shipping, routes through the Arctic. ${ }^{3}$ Modelling efforts using climate change projections illuminate the linkage between sea ice development and increasing shipping activities $[41,42]$ and have sparked high expectations for busy shipping traffic through the North. Yet others come to the conclusion that the usage of Arctic routes for global trade purposes is exaggerated due to its legal, infrastructural, technological, climatic, and economic challenges [43, 44, pp. 297-99]. Economic modelling efforts show a differentiated picture. Some studies find remarkable shifts in trade flows between Asia and Europe [45], while others do not expect economic benefits to occur with container traffic, but possibly with smaller-size bulk and cargo shipments [46]. ${ }^{4}$ Whether shipping numbers will increase depends on the kind of shipping going through the North, especially if the debate is about maritime trade or regionally focused shipping activities. While the former is not expected to increase significantly in the future, other regional development activities like oil and gas extraction and tourism are likely to contribute to rising regional shipping numbers [44, 48, pp. 26-30; 49].

Shipping prospects between north-eastern and northwestern routes also differ, with the former more likely to see increasing ship numbers $[8,44$, pp. 299-301], although the Northern Sea Route is still beset with many challenges [50, 51]. A tricky political and legal task ahead is to balance the interests and rights of the states bordering Arctic waterways with those states who (plan to) use Arctic routes, predominantly countries in East Asia [52]. Others are concerned with the increasing danger of shipping accidents due to higher traffic in the North [53] and environmental impacts through oil spills and emissions [54]. Finally, hopes for reducing emissions through shorter Arctic routes have been greeted sceptically

\footnotetext{
$\overline{3}$ For an aggregated overview of climate change impacts on transport and shipping, see [40, pp. 1591-3].

${ }^{4}$ For an overview of economic models applied to Arctic shipping, see [47].
}

because of the additional climate impact of emitting $\mathrm{CO}_{2}$ and other climate-forcers in the Arctic [55].

\section{Fisheries}

Social impacts in the fisheries sector may arise due to the possible change of fish populations in Arctic waters. These could result from climate-induced changes to the marine ecosystem, which may lead to more fortuitous conditions for some commercial fish stocks in the Arctic [56-59]. However, climate changes could also diminish stocks due to new predators, invasive species, and changing salinity and water temperature levels, to which some species are not able to adapt $[40$, p. $1591 ; 58$, p. $42 ; 59]$. Furthermore, only a few species have been found to be abundant enough to support viable fisheries in the Arctic Ocean [40, p. 1591] and only some are likely to move all that way north since they are not adapted to the different depth and temperature conditions of the deep Arctic Ocean $[58,59]$. While expanding fish habitats could result in new and expanded fishery prospects in Arctic waters, changing fish populations in terms of relative population sizes, growth rates, and spatial distributions could bring about negative effects on the investment-intensive and hard-to-adapt fishing industry and respective infrastructure [60, p. 692].

Contributions to existing literature generally highlight the significant amount of uncertainty when trying to assess the current and future impact of climatic changes on the Arctic's ecosystems and consequent effects on fisheries. This is due to the fact that climate models do not include all relevant parameters that affect fish stocks. Thus, any predictions about changing fisheries due to climate change can only be tentative [60, p. 692]. Knowledge as to the concrete changes on fish species also varies considerably between Arctic regions; while data on changes in fish distribution in the Barents and Bering Seas are well observed, the future of commercial fishing in the Arctic Ocean is uncertain [40, p. 1590;59, 61], which is of concern due to the limited regulatory framework in place [56, 62]. The changing nature of fish stocks in the Arctic are also relevant from a cultural point of view, since fishing is often part of traditional indigenous activities and diets in coastal regions [63]. It is argued that investing in fisheries and aquaculture could thus be a culturally sensitive approach to alleviate food insecurity that prevails in many Arctic regions [64, p. 16].

\section{Agriculture}

The possible climatic impacts on agricultural activities in the Arctic reveal a complex picture. For some, agriculture is seen as an underdeveloped sector in many parts of the North with the potential to improve food security and lessen dependence on food imports from outside the region [64, 65]. Further, a 
warmer climate could allow crop production to advance further north and increase average annual yields. For others, a warmer climate could also result in water deficits and increases in the incidence of insects and diseases with resulting negative impacts on crop yields $[40,66,67$, p. 782$]$.

But the climate is all but one determinant of the future of agriculture in the Arctic: Lack of infrastructure is likely to remain a major limiting factor for commercial agricultural development [67, p. 782]. But while thawing permafrost renders land transportation routes increasingly unusable, new shipping lanes could fundamentally change transport costs for Arctic agricultural products. Generally, agriculture is found to be less affected by a changing climate than by economic, structural, and social factors, such as government policies on agriculture and trade, technological adaptations, and environmental, geophysical, biological, and socio-economic challenges [66, 67, p. 782;68, p. 15]. Not least, while a boost of agricultural production could help in reducing food insecurity in Arctic regions, the cultural acceptance - and usefulness for local diets - of such activities may be limited since agriculture has not been part of traditional cultural livelihoods due to the lack of arable land in most Arctic regions [64, p. 9].

\section{Tourism}

Arctic regions are increasingly in focus as new tourist destinations. This is due to easier accessibility, increasing awareness, and an increased demand for so-called last chance tourism to see the icy wonders of the North before they disappear [69, p. 147 f.; 70, p. 137]. In some Arctic areas, tourism (especially cruise tourism [71, 72]) is one of the fastest growing economic sectors in the Arctic. Iceland in particular has seen vastly increasing tourist numbers in recent years $[69,73$, p. 5 f.], but in other areas the development of tourism has been prevented by limited infrastructure, fear of negative social and environmental impacts [73, p. 12], and/or regulatory hurdles [72].

The possible opportunities arising from tourism $[69,70, \mathrm{p}$. $137 ; 74]$ are often contrasted with concerns about the carrying capacity of Arctic tourist destinations in social, cultural, and environmental terms $[70$, p. 137; 73]. Further, local Arctic communities are often left to deal with the repercussions of tourism while benefits are reaped by big tour operators [73]. Such repercussions may play out in the form of increasing levels of pollution and waste, disturbance to wildlife, and disruption of everyday life and traditional activities in local communities [73]. Specifically, disruptions to cultural traditions may occur since Arctic tourism is often nature-based and nature is the foundation of Arctic traditional cultural ways of life [75]. This leads to questions about the possibilities and means of managing Arctic tourism activities sustainably [69, 71, 76, 77]. However, a single Arctic tourism does not exist since tourist numbers, the economic relevance of tourism [70, pp.
140-5], societal acceptance of marketing a place as a tourist destination, and environmental and social impacts all vary significantly across and within Arctic regions [69, p. 148; 73], such as in Nunavut [78] or Greenland [79].

\section{Impacts on Arctic Peoples and Players}

\section{Community and Urban Viability}

Different impacts occur in small-scale community settings in comparison to Arctic cities, which are confronted with various challenges of urbanisation processes and (changing) city-life $[80,81]$. Then again, especially the development of globally connecting communication technologies results in the fuzzy situation that " $[\mathrm{u}] \mathrm{rbanism}$ is no longer restricted to urban areas and rural life no longer epitomizes the "traditional" cultures" [82, p. 121]. Arctic cities, towns, and communities vary considerably in size, with some of them growing and others shrinking. Consequently, community and urban viability studies are usually focused on specific geographical places [80, 81, 83], for example on Greenland [84-86], Canada [87], or Finland [88], and examine how these places experience and deal with change in times of globalisation and climate change.

Climate change and globalisation affect community and urban viability and well-being ${ }^{5}$ via pathways such as demographic shifts in the form of migration and displacement [18, pp. 410-2; 90-93] and urbanisation and rural exodus [83, 89, 94, pp. 443-8]. The influx of newcomers to Arctic regions impacts livelihoods and lifestyles in the form of pressure on existing physical and social infrastructures, but this influx is also seen as providing opportunities in terms of mobility, advanced education, and career promotion $[29$, p. $225 ; 89$, p. 453 f.; 95, 96, p. 418].

Climate change and globalisation have a range of direct and indirect impacts on the health of Arctic populations, especially in small communities. Direct impacts include unsafe hunting conditions, risks to safe travel, and risks to subsistence activities due to changing and extreme weather events. Indirect health impacts encompass the changing availability of traditional country food and generally worsening food and water security [97-100, pp. 310-2; 101], changed patterns of infectious diseases [102], greater exposure to persistent organic pollutants and heavy metals $[103$, Ch. $8 ; 100$, p. 312 f.; 104], and unsafe built infrastructure. ${ }^{6}$ Importantly, the status of health and health impacts are very different across the Arctic, and health disparities are especially pronounced between indigenous and non-indigenous populations [100, pp. $302-10 ; 105]$. These challenges require assessment and

\footnotetext{
${ }^{5}$ For an overview of the state and change of community development in the Arctic, see [89].

${ }^{6}$ For an overview of direct and indirect health impacts, see [40 pp. 1581-3; 104].
} 
adaptation of health monitoring and health care infrastructure [99, 100, p. 300 f.; 104-107].

While much analysis is focused on the increasing accessibility of the Arctic due to the warming climate, climate change can also mean decreasing access, movement, and indeed living options across the North. Permafrost thaw, extreme weather events, flooding, diminishing sea and land ice, and coastal erosion result in unreliable ice roads, damage to houses, pipelines, railroads, airports, seaports, and effects on energy and water supply, sometimes requiring the relocation of entire communities, which could result in the abandonment of lifestyles and cultural traditions that have been established over thousands of years $[40$, p. $1591 ; 108-110]$. However, the concrete impacts of infrastructure change, the economic damage they cause, and adaptation responses vary significantly between Arctic regions [111-114]. The role of infrastructure in studies on societal change is increasingly acknowledged, for example in form of the "Rapid Arctic Transitions due to Infrastructure and Climate" (RATIC) project, which provides "a forum for developing and sharing new ideas and methods to assess, respond to, and adaptively managing the cumulative effects of Arctic infrastructure and climate change" $[115$, p. $1 ; 116]$.

\section{New Actors and Power Relations}

In response to Arctic transformation processes, the group of Arctic actors, or so-called stakeholders [117, p. 24 f.], has seen a tremendous enlargement [20]. The various scales outlined below hint at the multi-stakeholder landscape of Arctic politics and governance $[118,119]$. Many studies focus on the (usually vaguely defined) stakes of non-Arctic states, especially the Asian newcomers to the Arctic Council who recently received observer status (China, South Korea, Japan, Singapore, and India) [120-127], for example in relation to Arctic shipping [52, Pt. 4], Arctic oil and gas [128], and non-Arctic states' role in and for Arctic sustainability [129]. While much of this literature tends to analyse the role of new actors more from a threat or challenges perspective, some also highlight the opportunities for cooperation that arise through participation of economically and politically important players like China [130].

Other analyses examine more specifically the role and interests of China [131-137], the European Union [134, 136, 138-149], and the UK [150-155] in terms of their strategic and political interest in Arctic commodities, how they affect the environmental, economic, political, and legal developments in the North, and their historical linkage to and justification for a role in Arctic affairs. The implications of these 'new' or 'non-Arctic' players for specific Arctic states, like Canada [156] and Russia [157, 158], have also received attention. Non-Arctic states also appear in different membership categories in Arctic governance bodies; especially the enlarged group of observers to the Arctic Council has been scrutinised as to the institutional and procedural consequences for the Council [159-162].

Still somewhat underexposed is the role of supra-, sub-, and non-state actors in Arctic affairs, ranging from nongovernmental and intergovernmental organisations [163-166] and interparliamentary organisations [167] to actors from the sub-national and local level [117, p. 17 f.; 168 , 169] and the private sector [117, p. 16 f., 31]. Interesting topics in this regard are especially the changing nature of sub-national entities through political movements striving for more political independence or statehood (Greenland) [32, Ch. $2 ; 170-174]$ or stronger devolution on the sub-state level (Nunavut) [175]. Another interesting strand of literature is on the relationship between indigenous peoples and (extractive) industries [176] as well as the role of indigenous corporations and their impacts on the political power of indigenous peoples $[177,178]$. Some emphasise how the traditional Westphalian state system does not do justice to the new reality of multiple actor groups engaged in the Arctic [179-183], while others focus on how the engagement of transnational actors contributes to the state of complex interdependence in Arctic affairs [184]. Broadening the actor spectrum in Arctic affairs to include sub-state and non-state actors also reveals that political conflict-lines in the Arctic often do not run between states but rather within them [185].

\section{Role of Indigenous Peoples}

Changing ecosystems and concomitant socio-economic and political changes impact the culture and self-understanding of Arctic indigenous populations. Changing patterns of harvesting, hunting, and fishing have impacts on cultures, identities, and the value of traditional knowledge. This, in turn, leads to new economic configurations consisting of both a cash-based economy and traditional methods to acquire food and other commodities [40, p. 1583 f.; 186-189]. For example, changes in the timing of the ice melt affect traditional hunting prey like polar bears and some seal and walrus species that are dependent on sea ice for hunting or reproduction. Different precipitation, snow cover, and wildfire patterns affect grazing opportunities for reindeer and other herded animals, which result in altered habitat uses and migration patterns [190, pp. 119-27; 191].

The adoption of 'western' (see section "The ultimate drivers of Arctic change: Climate Change and Globalization") cultural norms can both be a source of negative cultural impacts in the form of abandonment of cultural traditions and language, but also of increasing social opportunities and indeed cultural empowerment through the reassertion of indigenous cultures [18, p. 418]. However, local languages are seen as in danger of disappearing in the wake of cultural globalisation, and thus 
preserving minority languages and language diversity, especially for indigenous groups, is a crucial piece in the changing culture puzzle of the Arctic [192-195, Ch. 15-18].

The increasing interest in the Arctic's natural resources also focuses attention on the rights to use or own land and resources, especially in relation to the right to self-determination of indigenous peoples who have lived on and used Arctic lands for much longer than any of the Arctic nation-states has existed [21, Ch. 7; 169, 177, 196-198]. New levels of accessibility in many Arctic regions and associated expectations for new economic activities often lead to conflict between traditional and new land-uses (and non-uses like nature conservation) [22, Pt. III; 199-201, Pt. II]. This can be seen in areas such as renewable and conventional energy development [22, 202, 203], tourism [69], reindeer husbandry [204], and sealing [205, 206]. Economic activities in the Arctic are thus often said to be subject to a social licence to operate, i.e. to receiving ongoing approval from a local community [207-214]. On the larger political scale, transformation processes may lead to movements striving for more political independence or statehood, which in the case of Greenland would result in a state with a majority Inuit population [32, Ch. 2; 170-174].

The role of indigenous peoples in and for Arctic governance is reflected in their special standing as rights-holders in Arctic affairs and as holders of traditional and local knowledge $[11,215]$. Indigenous peoples' role in regional and international governance is increasingly examined [196, 216-218] as well as their own efforts to build political agency grounded in the colonial history of many Arctic states [219, 220]. More broadly, contributions have contemplated using human rights as an ordering principle for Arctic governance to strengthen participation, information access, and the principle of free, prior, and informed consent for Arctic communities generally and indigenous peoples specifically [33, Ch. 5; 221-224]. Not least, the central position of indigenous peoples is reflected in the increasing number of indigenous researchers contributing to diverse aspects of the academic literature on Arctic change and its impacts [1, Ch. 11; 225-227].

It needs to be added that talking about "Arctic indigenous peoples" is a somewhat essentialising description of a complex, and indeed often incoherent, group; in fact, complexity is a defining feature of the Arctic's ethnicity in general [80, $p$. 83]. In many regions, it is even difficult to establish how many indigenous people there are in a given space and time since the question of who counts as indigenous and on which grounds is all but straightforward. Different jurisdictions have different answers for this: some use blood relation, some self-identification, some place of birth, and again others geographical location and group size. To complicate the picture even more, rules and regulations on indigenous peoples' status often change over time, making a historical comparison next to impossible [80, p. 85 f.; 228-230, p. 12-17]. Further, some censuses do not differentiate between different indigenous groups, e.g. between American Indians and Alaska Natives, and some do not register ethnicity in their official statistics at all. Lastly, while indigenous and non-indigenous peoples in the Arctic differ in their demographic characteristics and lifestyles, there is a trend towards greater 'mixing' between these groups, both in terms of habitation and identity [80, p. 85; 81, p. 29; 228, p. 134].

\section{Cross-cutting Themes of Arctic Societal Impacts}

\section{The Mantra of Sustainable Development and Sustainability}

In addition to the literature on specific sectors and actors, there are also several cross-cutting themes that one stumbles across frequently when studying the recent literature on societal impacts of a changing Arctic. While by no means exhaustive, two are particularly salient.

First, cutting across the above-mentioned impacts on sectors and actors is the by now well-established mantra of the sustainable development of Arctic or Arctic sustainability, which is penetrating policy and academic considerations on the Arctic alike. Next to historical and conceptual contributions on the sustainable development idea(l) $[231,232]$ in relation to different sectors (like oil and gas [34] or shipping [233]) and various Arctic regions [234], some contemplate the necessary policy changes in Arctic states to implement sustainable development [235]. Further, efforts are made to monitor and measure the state and change of human development and well-being in the Arctic in order to provide guidance as to the necessary steps to foster sustainable human development [1, 236, 237], for example by using knowledge-based economies to further the sustainable development of the Arctic [238], employing ecosystem services approaches to highlight the (monetary) value of Arctic resources and ecosystems [239], or by focusing on the centrality of human-natural systems for achieving sustainability [240]. Others contemplate the possible repercussions of pursuing sustainable development for the role of the state and the exercise of state sovereignty in an Arctic context [241]. The political and discursive power of sustainable development in the Arctic contextconcretely how the concept has enabled the opening of the Arctic for economic development rather than restraining it-is a refreshing new analytical viewpoint [242].

Many contributions focus on the possible sustainability consequences of new economic activities in the Arctic (see section "Impacts by societal sector"). While new economic opportunities arise, they also induce severe environmental impacts and risks [243]. This challenges subsistence-based lifestyles in terms of income development and inequality, and 
creates competition between established and new economic activities [221, 244] (see section "Role of indigenous peoples"). Further, limited opportunities of local populations to take part in new economic activities in the North need to be considered, for example because of a limited workforce (both in numbers and qualification) for new economic sectors [245], and an often-used fly-in-fly-out system for Arctic projects, which in turn impacts the social cohesion of communities [246-250]. Generally, while economic growth opportunities exist, Arctic economies will continue to be subject to uncertainty and volatility due to being increasingly intertwined with global economic developments [200, 251].

\section{The Tale of the Global Arctic}

A second cross-cutting theme derives from the relevance of globalisation processes for the Arctic (see section "The ultimate drivers of Arctic change: Climate Change and Globalization"). This is the tale of the Global Arctic, highlighting the inextricable linkages between Arctic and global processes and systems and thus the entangled fate of the North and the entire globe. This touches upon a variety of interlinkages: The warming of the Arctic is primarily caused by anthropogenic greenhouse gases emitted far beyond the Arctic Circle [252]; in turn, a warming Arctic is believed to impact weather and climate patterns further south [6, 253-255]. Beyond interactions in natural processes, contributions have focused on how the socio-economic situation of Arctic peoples is increasingly influenced by decisions taken elsewhere [189], how the pace and extent of Arctic oil and gas development is dependent on a multitude of outer-Arctic factors [185, 256], and which implications for foreign policy, sovereignty, and security arise in a globalised Arctic [257-260]. All this culminates in the plea for a global Arctic paradigm to be able to come to grips with the underlying processes and future pathways of Arctic transformations [261, 262].

\section{Conclusion}

Knowing about the impacts of the grand change processes of our time, above all climate change and globalisation, is useful both for academics studying causal relationships and for policy-makers taking decisions on mitigation and adaptation strategies for changing societal conditions. We can of course never be sure that the impacts we see today will be the impacts of tomorrow. Determining, studying, and drawing from anticipated impacts is a complicated endeavour in light of the fact that impacts can vary significantly in different localities and at different points in time. Not least, information is often limited since our observational data often does not go back a long time, and longitudinal and uninterrupted observations especially in challenging (and thus research cost-intensive) regions like the Arctic hardly exist. While natural systems show their significant degree of irregularity and unpredictability but also some numerical parameters to hold on to, venturing into the social world with often non-quantifiable and volatile concepts like norms, values, rules, interests, and preferences completes the picture of the complex task to study societal impacts of climate change and globalisation.

Six general observations, which are the author's own, stand out as to the current state of research on societal impacts of a changing Arctic. First, climate change and globalisation are the dominant drivers of societal impacts in the Arctic. Second, many contributions focus on the impacts of climate change and globalisation in concrete sectors of society, often from an opportunities-and-risks perspective, which tends to blur the boundary to more policy-oriented work. Third, the mantra of the sustainable development of the Arctic or Arctic sustainability pervades considerations of Arctic societal impacts. Fourth, societal impacts in the Arctic are increasingly analysed against the image of the Global Arctic, highlighting the inextricable linkages between Arctic and global processes and systems and thus the entangled fate of the North and the entire globe. Fifth, an increasing number of actors is seen as being involved in environmental and societal transformations in the Arctic, often conveyed through the ill-defined stakeholder concept. Sixth, Arctic indigenous peoples are depicted as the group most vulnerable to the impacts of a changing Arctic, but are increasingly the subject of research in the form of rights-holders and active participants in governance, law, politics, and research.

The reviewed societal impacts of a rapidly changing Arctic share three broad themes: complexity, uncertainty, and ambiguity. The societal impacts of a changing Arctic display complexity because they can never be regarded in isolation from their (assumed) causes and from other impacts, and they play out differently on various spatial and temporal scales. They are uncertain because a clear-cut assessment of impacts as positive or negative is often not easily done, and Arctic transformation is an ongoing process while limited observational data constrain our capacity to anticipate future impacts. Finally, they are ambiguous in that societal impacts often reveal a picture of opposites and blurring boundaries: transformation processes lead to increasing and decreasing access to the Arctic; global changes have local impacts and local changes have global impacts; the often-employed clear-cut division between Arctic and non-Arctic (e.g. in relation to actors, institutions, policies, and geographies) becomes increasingly fuzzy.

While the literature cited in this review is copious, not all of it takes academic rigour to be its primary goal. Indeed, we can observe a high level of enmeshment between especially political science contributions and popular science pieces targeting a broader audience beyond academia. Often these appear in 
the style used by mass media outlets, often in the form of contributions to topics of immediate policy relevance [263, p. 63]. This trend might be related to the new demand on researchers to include and be relevant for audiences beyond academic circles, often described with the terms integrated research, transdisciplinarity or science-policy dialogues [264-266]. While there is surely value to science-policy interactions, it should also be built on curiosity-driven, independent, and theoretically and methodologically aware research. Indeed, good policy advice can only be provided on the basis of trustworthy research results.

Another characteristic of contemporary Arctic research suggests a need for more conceptual clarity and reflexivity. One issue is the proliferation of buzzword usage in Arctic research on societal impacts: Who, and on which grounds, qualifies as an Arctic stakeholder? What is Arctic sustainable development? Do these concepts help to better understand systems and processes in the Arctic? To answer these questions, we need to critically reflect on these concepts, embed them in methodologically sound analytical frameworks, and then assess their usefulness for knowledgeenhancement and societal goal formulation and achievement. For sustainable development, some efforts in this regard are already discernible [267].

Another area of promise involves de-essentialising the Arctic by placing it in a more comparative context. Importantly, the changing Arctic and its impacts can be studied comparatively not only within the Arctic (which is surely valuable and necessary given the diversity of Arctic regions!) but also beyond the North. While definitely unique in many respects, the Arctic is not the only place on earth affected by global change processes, and inter-regional comparisons and historical analyses can only enrich our understanding of the Arctic (and of non-Arcticness) and its meaning for other places. Some efforts in this regard have been made in form of linking knowledge about the Arctic with and for places elsewhere $[268,269]$ but more research that is attentive to methods and theory would be desirable. In sum, while comparative efforts are methodologically and empirically demanding, they will decisively enrich our understanding of both the unique features of the Arctic and what the Arctic is a case of in terms of impacts from climate change and globalisation.

Acknowledgements The author would like to thank Pia Sommer and Ida Schepelmann from the IASS Potsdam as well as two anonymous reviewers for very helpful support in preparing this paper.

\section{Compliance with Ethical Standards}

Conflict of Interest The author states that there is no conflict of interest.

Human and Animal Rights and Informed Consent This article does not contain any studies with human or animal subjects performed by any of the authors.
Open Access This article is distributed under the terms of the Creative Commons Attribution 4.0 International License (http:// creativecommons.org/licenses/by/4.0/), which permits unrestricted use, distribution, and reproduction in any medium, provided you give appropriate credit to the original author(s) and the source, provide a link to the Creative Commons license, and indicate if changes were made.

\section{References}

1. AHDR (Arctic Human Development Report). Akureyri: Stefansson Arctic Institute; 2004.

2. Keskitalo ECH. Negotiating the Arctic - the construction of an international region. New York: Routledge; 2004.

3. ACIA. Impacts of a warming Arctic: Arctic climate impact assessment. Cambridge: Cambridge University Press; 2004.

4. Steinberg PE, Tasch J, Gerhardt H, editors. Contesting the Arctic - politics and imaginaries in the Circumpolar North. London: I.B.Tauris \& Co Ltd; 2015.

5. Carson M, Peterson J, editors. Arctic Council. Arctic Resilience Report. Stockholm: Stockholm Environment Institute and Stockholm Resilience Centre; 2016.

6. Arctic Monitoring and Assessment Programme (AMAP). Snow, water, ice and permafrost. Summary for policy-makers. Oslo: Arctic Monitoring and Assessment Programme (AMAP); 2017.

7. Keskitalo ECH, Nuttall M. Globalization of the "Arctic". In: Evengård B, Larsen JN, Paasche Ø, editors. The new Arctic. Heidelberg: Springer; 2015. p. 175-88.

8. Østreng W, et al. Shipping in Arctic waters: a comparison of the Northeast, Northwest and trans polar passages. Berlin: Springer; 2013.

9. Heininen L, Southcott C, editors. Globalization and the Circumpolar North. Fairbanks: University of Alaska Press; 2010.

10. Keskitalo ECH. Climate change and globalization in the Arctic: an integrated approach to vulnerability assessment. Abingdon: Routledge; 2008.

11. Hensley WII. Iggiagruk is my Inupiaq name. In: Pelaudeix C, Faure A, Griffiths R, editors. What holds the Arctic together? Paris: L'Harmattan; 2012. p. 43-50.

12. Emmerson C. The future history of the Arctic. New York: Public Affairs; 2010.

13. Sale R, Potapov E. The scramble for the Arctic — ownership, exploitation and conflict in the Far North. London: Frances Lincoln Limited; 2010.

14. Vaughan R. The Arctic - a history. Chalford: Sutton Publishing; 2007.

15. Lainema M, Nurminen J. A history of Arctic exploration- discovery, adventure and endurance at the top of the world. London: Conway; 2001.

16. Southcott C. History of globalization in the Circumpolar North. In: Heininen L, Southcott C, editors. Globalization and the Circumpolar North. Fairbanks: University of Alaska Press; 2010. p. 23-55.

17. Heininen L, Southcott C. Globalization and the Circumpolar North - an introduction. In: Heininen L, Southcott C, editors. Globalization and the Circumpolar North. Fairbanks: University of Alaska Press; 2010. p. 1-22.

18. Keskitalo ECH, Southcott C, Rasmussen RO, Tollefsen A, Crate S. Globalization. In: Larsen JN, Fondahl G, editors. Arctic human development report-regional processes and global linkages. Copenhagen: Nordic Council of Ministers; 2015. p. 401-25. 
19. Murray RW. Arctic politics in the emerging multipolar system. Challenges and consequences. Polar J. 2012;2(1):7-20.

20. Avango D, Nilsson AE, Roberts P. Assessing Arctic futures: voices, resources and governance. Polar J. 2013;3(2):431-46.

21. Byers M. International law and the Arctic. New York: Cambridge University Press; 2013.

22. Pelaudeix C, Basse EM, editors. Governance of Arctic offshore oil and gas. Abingdon: Routledge; 2018.

23. Tedsen E, Cavalieri S, Kraemer RA, editors. Arctic marine governance-opportunities for transatlantic cooperation. Berlin Heidelberg: Springer; 2014.

24. Weidemann L. International governance of the Arctic marine environment. Hamburg: Springer; 2014.

25. Molenaar EJ. Adapting governance and regulation of the marine Arctic. In: Powell RC, Doods K, editors. Polar Geopolitics? Knowledges, Resources and Legal Regimes. Cheltenham: Edward Elgar; 2014. p. 74-92.

26. Molenaar EJ, Elferink AG, Rothwell DR. The law of the sea and the polar regions: interactions between global and regional regimes. Leiden: Brill Nijhoff; 2013.

27. Chater A, Landriault M. Understanding media perceptions of the Arctic council. In: Heininen L, Exner-Pirot H, Plouffe J, editors. Arctic Yearbook 2016 - The Arctic Council: 20 Years of Regional Cooperation and Policy-Shaping. Akureyri: Northern Research Forum; 2016. p. 75-89.

28. Christensen M, Nilsson AE, Wormbs N, editors. Media and the politics of Arctic climate change. When the ice breaks. Basingstoke: Palgrave Macmillan; 2013.

29. Stepien A, Banul K, Scheepstra A, van Dam K, Latola K, Koivurova T. Socioeconomic and cultural challenges in the European Arctic. In: Stepien A, Koivurova T, Kankaanpää P, editors. The changing Arctic and the European Union. Leiden: Brill Nijhoff; 2015. p. 213-42.

30. Gautier DL, et al. Assessment of undiscovered oil and gas in the Arctic. Science. 2009;324:1175-9.

31. Bird KJ et al. Circum-Arctic Resource Appraisal: Estimates of Undiscovered Oil and Gas North of the Arctic Circle. USGS Fact Sheet, U.S. Department of the Interior, U.S. Geological Survey; 2008.

32. Ulfbeck V, Møllmann A, Mortensen BOG, editors. Responsibilities and liabilities for commercial activity in the Arctic - the example of Greenland. Abingdon: Routledge; 2016.

33. Johnstone RL. Offshore oil and gas development in the Arctic under international law-risk and responsibility. Leiden: Brill Nijhoff; 2015.

34. Mikkelsen A, Langhelle O. Arctic oil and gas - sustainability at risk? Abingdon: Routledge; 2008.

35. Forbes BC, Stammler F, Kumpula T, Meschtyb N, Pajunen A, Kaarlejärvi E. High resilience in the Yamal-Nenets social-ecological system, West Siberian Arctic. Russia Proc Natl Acad Sci. 2009;106(52):22041-8.

36. Keil $\mathrm{K}$. The Arctic in a global energy picture: international determinants of Arctic oil and gas development. In: Keil K, Knecht S, editors. Governing Arctic change: global perspectives. Basingstoke: Palgrave Macmillan; 2017. p. 279-99.

37. Gulas S, Downton M, D'Souza K, Hayden K, Walker TR. Declining Arctic Ocean oil and gas developments: opportunities to improve governance and environmental pollution control. Mar Policy. 2017;75:53-61.

38. Bourmistrov A, Mellemvik F, Bambulyak A, Gudmestad O, Overland I, Zolotukhin A, editors. International Arctic Petroleum Cooperation - Barents Sea scenarios. Abingdon: Routledge; 2016.

39. Koivurova T. Race to resources in the Arctic: have we progressed in our understanding of what takes place in the Arctic? In:
Evengård B, Larsen JN, Paasche $\varnothing$, editors. The new Arctic. Heidelberg: Springer; 2015. p. 189-202.

40. Larsen JN, et al. Polar Regions. In: Barros VR, Field CB, Dokken DJ, Mastrandrea MD, Mach KJ, Bilir TE, Chatterjee M, Ebi KL, Estrada YO, Genova RC, Girma B, Kissel ZS, Levy AN, MacCracken S, Mastrandrea PR, White LL, editors. Climate change 2014: impacts, adaptation, and vulnerability. Part B: regional aspects. Contribution of Working Group II to the Fifth Assessment Report of the Intergovernmental Panel on Climate Change. Cambridge: Cambridge University Press; 2014. p. 1567-612.

41. Stephenson SR, Smith LC, Brigham LW, Agnew JA. Projected 21 st-century changes to Arctic marine access. Clim Chang. 2013;118(3-4):885-99.

42. Smith LC, Stephenson SR. New trans-Arctic shipping routes navigable by midcentury. Proc Natl Acad Sci. 2013;13:6-10.

43. Farré $\mathrm{AB}$, et al. Commercial Arctic shipping through the Northeast Passage: routes, resources, governance, technology, and infrastructure. Polar Geogr. 2014;37(4):298-324.

44. Guy E, Lasserre F. Commercial shipping in the Arctic: new perspectives, challenges and regulations. Polar Rec. 2016;52(264): 294-304.

45. Bekkers E, Francois JF, Rojas-Romagosa H. Melting ice caps and the economic impact of opening the Northern Sea Route. CPB Netherlands Bur Econ Policy Anal. 2015;307:1-45.

46. Zhang Y, Meng Q, Ng SH. Shipping efficiency comparison between Northern Sea Route and the conventional Asia-Europe shipping route via Suez Canal. J Transp Geogr. 2016;57:241-9.

47. Lasserre F. Simulations of shipping along Arctic routes: comparison, analysis and economic perspectives. Polar Rec. 2014;51(3): 239-59.

48. Keil K. Economic potential. In: Jokela J, editor. Arctic security matters, No. 24. Brussels: European Union Institute for Security Studies (EUISS); 2015. p. 21-31.

49. Moe A. International use of the Northern Sea Route - trends and prospects. In: Lunde L, Jian Y, Stensdal I, editors. Asian countries and the Arctic future. Singapore: World Scientific Publishing; 2015. p. 107-20.

50. Moe A. The Northern Sea Route: smooth sailing ahead? In: Sinha UK, Bekkevold JL, editors. Arctic: commerce, governance and policy. Abingdon: Routledge; 2015. p. 18-36.

51. Pastusiak T. The Northern Sea Route as a shipping lane. Heidelberg: Springer; 2016.

52. Beckman RC, Henriksen T, Kraabel KD, Molenaar EJ, Roach JA. Governance of Arctic shipping - balancing rights and interests of Arctic states and user states. Leiden: Brill Nijhoff; 2017.

53. Afenyo M, Khan F, Veitch B, Yang M. Arctic shipping accident scenario analysis using Bayesian Network approach. Ocean Eng. 2017;133:224-30.

54. Mjelde A, Martinsen K, Eide M, Endresen Ø. Environmental accounting for Arctic shipping - a framework building on ship tracking data from satellites. Mar Pollut Bull. 2014;87(1-2):22-8.

55. Lindstad H, Bright RM, Strømman AH. Economic savings linked to future Arctic shipping trade are at odds with climate change mitigation. Transp Policy. 2016;45:24-30.

56. Christiansen JS, Mecklenburg CW, Karamushko OV. Arctic marine fishes and their fisheries in light of global change. Glob Chang Biol. 2014;20:352-9.

57. Bouchard $\mathrm{C}$, et al. Climate warming enhances polar cod recruitment, at least transiently. Prog Oceanogr. 2017;156:121-9.

58. Haug T, et al. Future harvest of living resources in the Arctic Ocean north of the Nordic and Barents Seas: a review of possibilities and constraints. Fish Res. 2017;188:38-57.

59. Hollowed AB, Planque B, Loeng H. Potential movement of fish and shellfish stocks from the sub-Arctic to the Arctic Ocean. Fish Oceanogr. 2013;22(5):355-70. 
60. Vilhjálmsson H, Hoel AH. Fisheries and aquaculture. In: Walsh JE, editor. Arctic climate impact assessment - scientific report. Cambridge: Cambridge University Press; 2005. p. 691-780.

61. Sigurjónsson J. Changes in distribution and migration of fish stocks in the Northeast Atlantic Ocean due to climate variations. In: Nordquist MH, Moore JN, Long R, editors. Challenges of the changing Arctic - continental shelf, navigation, and fisheries. Leiden: Brill Nijhoff; 2016. p. 405-28.

62. Norris AJ, McKinley P. The Central Arctic Ocean-preventing another tragedy of the commons. Polar Rec. 2017;53(1):43-51.

63. Nuttall M, Berkes F, Forbes B, Kofinas G, Vlassova T, Wenzel G. Hunting, herding, fishing and gathering: indigenous peoples and renewable resource use in the Arctic. In: Walsh JE, editor. Arctic climate impact assessment—scientific report. Cambridge: Cambridge University Press; 2005. p. 649-90.

64. Stecyk K. Good governance of food security in Nunavut. J Food Res. 2018;7(4):7-22.

65. Stevenson KT, et al. Sustainable agriculture for Alaska and the Circumpolar North: part I. Development and status of northern agriculture and food security. Arctic. 2014;67(3):271-95.

66. Stevenson KT, et al. Sustainable agriculture for Alaska and the Circumpolar North: part II. Environmental, geophysical, biological and socioeconomic challenges. Arctic. 2014;67(3):296-319.

67. Juday GP. Arctic climate impact assessment — scientific report. In: Arris L, editor. Forests, land management, and agriculture. Cambridge: Cambridge University Press; 2004. p. 781-862.

68. Arctic Monitoring and Assessment Programme (AMAP). Adaptation Actions for a Changing Arctic (AACA) - Barents Area Overview report. Oslo: Arctic Monitoring and Assessment Programme (AMAP); 2017.

69. Müller DK. Issues in Arctic tourism. In: Evengård B, Larsen JN, Paasche Ø, editors. The new Arctic. Heidelberg: Springer; 2015. p. 147-58.

70. Grimsrud K. Tourism in the Arctic: economic impacts. In: Glomsrød S, Duhaime G, Aslaksen J, editors. The Economy of the North 2015. Oslo: Statistics Norway; 2017. p. 137-47.

71. Luck M, Maher PT, Stewart EJ, editors. Cruise tourism in polar regions: promoting environmental and social sustainability? Abingdon: Earthscan; 2010.

72. Dawson J, Johnston M, Stewart E. The unintended consequences of regulatory complexity: the case of cruise tourism in Arctic Canada. Mar Policy. 2017;76:71-8.

73. Maher PT, et al. Arctic tourism: realities \& possibilities. In: Heininen L, Exner-Pirot H, Plouffe J, editors. Arctic Yearbook 2014-Human Capital in the North. Akureyri: Northern Research Forum; 2014. p. 290-306.

74. Kristjánsdóttir KR. Work creates community: the role of tourism in sustainable development of a European Arctic Community. In: Heininen L, Exner-Pirot H, Plouffe J, editors. Arctic Yearbook 2014-Human Capital in the North. Akureyri: Northern Research Forum; 2014. p. 273-89.

75. Stewart EJ, Dawson J, Draper D. Cruise tourism and residents in Arctic Canada: development of a resident attitude typology. J Hosp Tour Manag. 2011;18(1):95-106.

76. Bystrowska M, Wigger K, Liggett D. The use of information and communication technology (ICT) in managing high Arctic tourism sites: a collective action perspective. Resources. 2017;6(3):118.

77. Bickford N, Smith L, Bickford S, Bice MR, Ranglack DH. Evaluating the role of CSR and SLO in ecotourism: collaboration for economic and environmental sustainability of Arctic resources. Resources. 2017;6:21. https://doi.org/10.3390/ resources6020021.

78. Johnston ME, Dawson J, Maher PT. Strategic development challenges in marine tourism in Nunavut. Resources. 2017;6:25. https://doi.org/10.3390/resources6030025.
79. Tommasini D. Tourism, human capital \& regional development in three communities in Greenland: Ukkusissat, Narsaq and Qaanaaq. In: Heininen L, Exner-Pirot H, Plouffe J, editors. Arctic Yearbook 2014 -Human Capital in the North. Akureyri: Northern Research Forum; 2014. p. 244-56.

80. Heleniak T, Bogoyavlensky D. Arctic populations and migration. In: Larsen JN, Fondahl G, editors. Arctic human development report-regional processes and global linkages. Copenhagen: Nordic Council of Ministers; 2015. p. 53-104.

81. Bogoyavlenskiy D, Siggner A. Arctic demography. In: Arctic human development report. Stefansson Arctic Institute: Akureyri; 2004. p. $27-41$.

82. Dybbroe S, Dahl J, Müller-Wille L. Dynamics of Arctic urbanization. Acta Boreal - A Nord J Circumpolar Soc. 2010;27(2):120-4.

83. Hansen KG, Bitsch S, Zalkind L, editors. Urbanization and the role of housing in the present development process in the Arctic, Nordregio Report 2013:3. Stockholm; 2013.

84. Grydehøj A. Constructing a centre on the periphery: urbanization and urban design in the island city of Nuuk. Greenland Isl Stud J. 2014;9(2):205-22.

85. Dahl J. Identity, urbanization and political demography in Greenland. Acta Boreal - A Nord J Circumpolar Soc. 2010;27(2):125-40.

86. Sejersen F. Urbanization, landscape appropriation and climate change in Greenland. Acta Boreal - A Nord J Circumpolar Soc. 2010;27(2):167-88.

87. Farish M, Lackenbauer WP. High modernism in the Arctic: planning Frobisher Bay and Inuvik. J Hist Geogr. 2009;35(3):517-44.

88. Müller-Wille L. Precursors of urban processes in Finnish Sápmi in the 1960s. Acta Boreal - A Nord J Circumpolar Soc. 2010;27(2): 141-50.

89. Rasmussen RO, et al. Community viability and adaptation. In: Larsen JN, Fondahl G, editors. Arctic human development report-regional processes and global linkages. Copenhagen: Nordic Council of Ministers; 2015. p. 427-78.

90. Heleniak T. Migration in the Arctic. In: Heininen L, Exner-Pirot H, Plouffe J, editors. Arctic Yearbook 2014 -Human Capital in the North. Akureyri: Northern Research Forum; 2014. p. 82-104.

91. Crate SA. Climate change and human mobility in indigenous communities of the Russian North. Washington, DC: Brookings; 2013.

92. Ferris E. A complex constellation: displacement, climate change and Arctic peoples. Washington, DC: Brookings; 2013.

93. Schmidt JI, Aanesen M, Klokov KB, Khrutschev S, Hausner VH. Demographic and economic disparities among Arctic regions. Polar Geogr. 2015;38(4):251-70.

94. Weber R, et al. Urbanisation and land use management in the arctic: an investigative overview. In: Fondahl G, Wilson GN, editors. Northern sustainabilities: understanding and addressing change in the Circumpolar World. Heidelberg: Springer; 2017. p. 269-84.

95. Hirshberg D, et al. Education and human capital. In: Larsen JN, Fondahl G, editors. Arctic human development report—regional processes and global linkages. Copenhagen: Nordic Council of Ministers; 2015. p. 350-99.

96. Keskitalo ECH, Southcott C. Globalization. In: Larsen JN, Fondahl G, editors. Arctic human development report - regional processes and global linkages. Copenhagen: Nordic Council of Ministers; 2015. p. 397-422.

97. Nilsson LM, Evengård B. Food security or food sovereignty: what is the main issue in the Arctic? In: Evengård B, Larsen $\mathrm{JN}$, Paasche Ø, editors. The new Arctic. Heidelberg: Springer; 2015. p. 213-24.

98. Bring A, Jarsjö J, Destouni G. Water information and water security in the Arctic. In: Evengård B, Larsen JN, Paasche Ø, editors. The new Arctic. Heidelberg: Springer; 2015. p. 225-38. 
99. Rosol R, Powell-Hellyer S, Chan HM. Impacts of decline harvest of country food on nutrient intake among Inuit in Arctic Canada: impact of climate change and possible adaptation plan. Int $\mathrm{J}$ Circumpolar Health. 2016;75. https://doi.org/10.3402/ijch.v75. 31127.

100. Rautio A, Poppel B, Young K, Emelyanova A, Juutilainen A, Sunnari V. Human health and wellbeing. In: Larsen JN, Fondahl G, editors. Arctic human development report-regional processes and global linkages. Copenhagen: Nordic Council of Ministers; 2015. p. 299-348.

101. Todd Z. Food Security, Arctic security: why the local cannot be ignored. In: Daveluy M, Lévesque F, Ferguson J, editors. Humanizing security in the Arctic. Edmonton: CCI Press; 2011. p. 207-24.

102. Parkinson A, Koch A, Evengård B. Infectious disease in the Arctic: a panorama in transition. In: Evengård B, Larsen JN, Paasche Ø, editors. The new Arctic. Heidelberg: Springer; 2015. p. 239-58.

103. Stone DP. The changing Arctic environment. The Arctic messenger. Cambridge: Cambridge University Press; 2015.

104. Rautio A. Environmental health in the changing Arctic. In: Evengård B, Larsen JN, Paasche Ø, editors. The new Arctic. Heidelberg: Springer; 2015. p. 259-68.

105. Young K, Chatwood S. Comparing the health of circumpolar populations: patterns, determinants, and systems. In: Evengård B, Larsen JN, Paasche $\varnothing$, editors. The new Arctic. Heidelberg: Springer; 2015. p. 203-12.

106. Giles AR, Brooks-Cleator LA, Glass CTR. Barriers to sustainable health promotion and injury prevention in the Northwest Territories, Canada. In: Fondahl G, Wilson GN, editors. Northern sustainabilities: understanding and addressing change in the Circumpolar World. Heidelberg: Springer; 2017. p. 151-62.

107. Linstad L. Telemedicine as a tool for improving human security. In: Gjørv GH, Bazely D, Marina G, Tanentzap A, editors. Environmental and human security in the Arctic. London: Routledge; 2014. p. 153-62.

108. Arenas-Hidalgo N. The national and international approach to native community relocation in the Arctic. In: Conde E, Sánchez SI, editors. Global challenges in the Arctic region: sovereignty, environment and geopolitical balance. Abingdon: Routledge; 2017. p. 254-78.

109. Romanovsky $\mathrm{V}$ et al. Changing permafrost and its impacts. In: Snow, Water, Ice and Permafrost in the Arctic (SWIPA). Oslo: Arctic Monitoring and Assessment Programme (AMAP); 2017. p. $65-102$.

110. Pearce T, Smit B. Vulnerability and adaptation to climate change in the Canadian Arctic. Clim Vulnerability. 2013;4:293-303.

111. SDWG. The Economy of the North 2015. Oslo: Statistics Norway; 2017.

112. Melvin AM, et al. Climate change damages to Alaska public infrastructure and the economics of proactive adaptation. Proc Natl Acad Sci. 2017;114(2):E122-31.

113. Baztan J, Cordier M, Huctin J-M, Zhu Z, Vanderlinden J-P. Life on thin ice. Insights from Uummannaq, Greenland for connecting climate science with Arctic communities. Polar Sci. 2017;13: $100-8$.

114. Instanes A, Anisimov O. Climate change and Arctic infrastructure, In: Proceedings of the 9th International Conference on Permafrost (NICOP). Fairbanks; 2008. p. 779-84.

115. Walker DA, Peirce JL. Rapid Arctic Transitions due to Infrastructure and Climate (RATIC): a contribution to ICARP III, Alaska Geobotany Center Publication AGC 15Z 02. Fairbanks: University of Alaska Fairbanks; 2015.

116. Raynolds MK, et al. Cumulative geoecological effects of 62 years of infrastructure and climate change in icerich permafrost landscapes, Prudhoe Bay Oilfield, Alaska. Glob Chang Biol. 2014;20:1211-24.

117. Duyck S. Polar Environmental Governance and Nonstate Actors. In: Pincus R, Ali SH, editors. Diplomacy on ice - energy and the environment in the Arctic and Antarctic. New Haven: Yale University Press; 2015. p. 13-40.

118. Stokke OS. Political stability and multi-level governance in the Arctic. In: Berkman PA, Vylegzhanin AN, editors. Environmental security in the Arctic Ocean. Dordrecht: Springer Science+Business Media; 2013. p. 297-311.

119. Stokke OS. Regime interplay in Arctic shipping governance: explaining regional niche selection. Int Environ Agreements Polit Law Econ. 2013;13(1):65-85.

120. Tonami A. Asian foreign policy in a changing Arctic. The diplomacy of economy and science at new frontiers. UK: Palgrave Macmillan; 2016.

121. Jakobson L, Lee S-H. North East Asia eyes the Arctic. In: Jakobson L, Melvin N, editors. The new Arctic governance. Oxford: Oxford University Press; 2016. p. 111-46.

122. Lunde L, Yang J, Stensdal I, editors. Asian countries and the Arctic future. Singapore: World Scientific Publishing; 2015.

123. Hong N, Nuttall AD. Emerging interests of non-Arctic countries in the Arctic - China, Japan, South Korea, and India. In: Murray $\mathrm{RW}$, Nuttall AD, editors. International relations and the Arcticunderstanding policy and governance. Amherst: Cambria Press; 2014. p. 573-98.

124. Hara K, Coates K, editors. East Asia-Arctic relations: boundary, security and international politics. Waterloo: Center for International Governance Innovation; 2014.

125. Sinha UK, Bekkevold JI. Arctic: commerce, governance and policy. Abingdon: Routledge; 2015.

126. Ikeshima T. Geopolitical dynamics in the Arctic: actors and global interests. In: Conde E, Sánchez SI, editors. Global challenges in the Arctic region: sovereignty, environment and geopolitical balance. Abingdon: Routledge; 2017. p. 385-401.

127. Heininen L, Exner-Pirot H, Plouffe J, editors. Arctic Yearbook 2013 - the Arctic of regions vs. the globalized Arctic. Akureyri: Northern Research Forum; 2013.

128. Peimani H. Energy security and geopolitics in the Arctic - challenges and opportunities in the 21st century. Singapore: World Scientific Publishing; 2012.

129. Coates K, Holroyd C. Non-Arctic states and their stake in Arctic sustainability. In: Keil K, Knecht S, editors. Governing Arctic change: global perspectives. Basingstoke: Palgrave Macmillan; 2017. p. 207-28.

130. Pan M, Huntington HP. A precautionary approach to fisheries in the Central Arctic Ocean: policy, science, and China. Mar Policy. 2016;63:153-7.

131. Brady A-M. China as a polar great power. Cambridge: Cambridge University Press; 2017.

132. Perreault F. The role(s) of China in the Arctic: regional governance and foreseeable challenges. In: Conde E, Sánchez SI, editors. Global challenges in the Arctic region: sovereignty, environment and geopolitical balance. Abingdon: Routledge; 2017. p. 420-41.

133. Zeuthen J. Part of the master plan? Chinese investment in rare earth mining in Greenland. In: Heininen L, Exner-Pirot H, Plouffe J, editors. Arctic Yearbook 2017-Change and innovation. Akureyri: Northern Research Forum; 2017. p. 312-25.

134. Goodsite ME, Bertelsen RG, Pertoldi-Bianchi SC, Ren J, van der Watt L-M, Johannsson H. The role of science diplomacy: a historical development and international legal framework of arctic research stations under conditions of climate change, post-cold war geopolitics and globalization/power transition. J Environ Stud Sci. 2016;6(4):645-61. 
135. Huang L, Lasserre F, Alexeeva OI. China's interest for the Arctic driven by Arctic shipping potential? Asian Geogr. 2015;32(1):59 71.

136. Pelaudeix C. China's interest in the Arctic and the EU's Arctic policy: towards a proactive EU foreign policy? In: Alfredsson G, Koivurova T, Jabour J, editors. The yearbook of polar law, vol. 7. Leiden: Martinus Nijhoff Publishers; 2015. p. $128-50$.

137. Liu N. China's role in the changing governance of Arctic shipping. In: Alfredsson G, Koivurova T, Agústsson HO, editors. The yearbook of polar law, vol. 6. Leiden: Martinus Nijhoff Publishers; 2014. p. 545-58.

138. Raspotnik A. The European Union and the Geopolitics of the Arctic. Cheltenham: Edward Elgar; 2018.

139. Basse EM. The EU's role as a facilitator in the development of maritime environmental law in the Arctic: with focus on offshore hydrocarbon activities. In: Pelaudeix C, Basse EM, editors. Governance of Arctic Offshore Oil and Gas. Abingdon: Routledge; 2018. p. 47-71.

140. Pelaudeix C. EU-Greenland relations and sustainable development in the Arctic. In: Conde E, Sánchez SI, editors. Global challenges in the Arctic region: sovereignty, environment and geopolitical balance. Abingdon: Routledge; 2017. p. 306-24.

141. Stepien A, Koivurova T, Kankaanpää P, editors. The changing Arctic and the European Union. Leiden: Brill Nijhoff; 2016.

142. Long R. Arctic governance: reflections on the evolving tableau of EU law and policy measures. In: Nordquist MH, Moore JN, Long R, editors. Challenges of the changing Arctic - continental shelf, navigation, and fisheries. Leiden: Brill Nijhoff; 2016. p. 363-99.

143. Stępień A, Raspotnik A. The EU's Arctic future following the spring of statements. In: Heininen L, Exner-Pirot H, Plouffe J, editors. Arctic Yearbook 2016 - the Arctic Council: 20 years of regional cooperation and policy-shaping. Akureyri: Northern Research Forum; 2016. p. 438-42.

144. Stępień A. Internal contradictions and external anxieties: one 'coherent' Arctic policy for the European Union? In: Alfredsson G, Koivurova T, Jabour J, editors. The yearbook of polar law, vol. 7. Leiden: Martinus Nijhoff Publishers; 2015. p. 249-89.

145. Keil K, Raspotnik A. The European Union's gateways to the Arctic. Eur Foreign Aff Rev. 2014;19(1):101-20.

146. Tedsen E et al. Gap Analysis Report. Preparatory action, strategic environmental impact assessment of development of the Arctic. Arctic Centre, University of Lapland; 2014. p. 1-103.

147. Archer C. The Arctic and the European Union. In: Murray RW, Nuttall AD, editors. International relations and the Arctic - understanding policy and governance. Amherst: Cambria Press; 2014. p. $383-410$.

148. Archer C. International and regional regulation of the Arctic: is there a role for the European Union? In: Pelaudeix C, Faure A, Griffiths R, editors. What holds the Arctic together? Paris: L'Harmattan; 2012. p. 169-82.

149. Luszczuk M, Justus D, Thomas J, Klok C, Gerber F. Arctic offshore hydrocarbons and the European Union: more constrains and less opportunities. In: Stepien A, Koivurova T, Kankaanpää P, editors. The changing Arctic and the European Union. Leiden: Brill Nijhoff; 2016. p. 137-62.

150. Depledge D. Britain and the Arctic. Basingstoke: Palgrave Macmillan; 2018.

151. Johnstone RL. Respectful neighbourliness: the United Kingdom's Arctic approach. In: Alfredsson G, Koivurova T, Baker B, Kimmel M, editors. The yearbook of polar law, vol. 8. Leiden: Martinus Nijhoff Publishers; 2016. p. 27-55.
152. Depledge D. (Re)assembling Britain's Arctic. In: Powell RC, Dodds K, editors. Polar geopolitics? Knowledges, Resources and Legal Regimes. Cheltenham: Edward Elgar; 2014. p. 183200.

153. Dodds K. A work in progress-The United Kingdom and the Arctic region. In: Murray RW, Nuttall AD, editors. International relations and the Arctic - understanding policy and governance. Amherst: Cambria Press; 2014. p. 551-72.

154. Bailes A. The Arctic's nearest neighbour? An evaluation of the UK's 2013 Arctic policy document. In: Heininen L, Exner-Pirot H, Plouffe J, editors. Arctic Yearbook 2014-Human Capital in the North. Akureyri: Northern Research Forum; 2014. p. 380-98.

155. Depledge D. Assembling a (British) Arctic. Polar J. 2013. No. May: 1-15.

156. Lackenbauer PW, Lajeunesse A, Manicom J, Lasserre F. China's Arctic ambitions and what they mean for Canada. Calgary: University of Calgary Press; 2018.

157. Ufimtseva A, Prior T. Developing Hydrocarbon resources in Arctic Russia: the role of Sino-Russian collaboration. In: Heininen L, Exner-Pirot H, Plouffe J, editors. Arctic Yearbook 2017-change and innovation. Akureyri: Northern Research Forum; 2017. p. 368-76.

158. Røseth T. Russia's China policy in the Arctic. Strateg Anal. 2014;38(6):841-59.

159. Graczyk P, Śmieszek M, Koivurova T, Stęień A. Preparing for the Global Rush: the Arctic Council, institutional norms, and socialisation of observer behaviour. In: Keil K, Knecht S, editors. Governing Arctic change: global perspectives. Basingstoke: Palgrave Macmillan; 2017. p. 121-40.

160. Knecht S. Exploring different levels of stakeholder activity in international institutions: late bloomers, regular visitors, and overachievers in Arctic Council Working Groups. In: Keil K, Knecht S, editors. Governing Arctic change: global perspectives. Basingstoke: Palgrave Macmillan; 2017. p. 163-86.

161. Ingimundarson V. Managing a contested region: the Arctic Council and the politics of Arctic governance. Polar J. 2014;4(1):183-98.

162. Chater A. Explaining non-Arctic states in the Arctic Council. Strateg Anal. 2016;40(3):173-84.

163. Knecht $\mathrm{S}$. The politics of Arctic international cooperation: introducing a dataset on stakeholder participation in Arctic Council meetings, 1998-2015. Coop Confl. 2016;52(2):203-23.

164. Wehrmann D. Non-state actors in Arctic Council governance. In: Keil K, Knecht S, editors. Governing Arctic change: global perspectives. Basingstoke: Palgrave Macmillan; 2017. p. 187-206.

165. Knight WA. The United Nations on Arctic issues. In: Murray RW, Nuttall AD, editors. International relations and the Arctic - understanding policy and governance. Amherst: Cambria Press; 2014. p. 411-40.

166. Koivurova T. Multipolar and multilevel governance in the Arctic and the Antarctic. Am Soc Int Law Proc Annu Meet. 2013;107: 443-6.

167. Łuszczuk M. Inter-parliamentary institutions \& Arctic governance. In: Heininen L, Exner-Pirot H, Plouffe J, editors. Arctic Yearbook 2015-Arctic governance and governing. Akureyri: Northern Research Forum; 2015. p. 195-213.

168. Olsen IH, Shadian JM. Greenland and the Arctic Council: subnational regions in a time of Arctic Westphalianisation. In: Heininen L, Exner-Pirot H, Plouffe J, editors. Arctic Yearbook 2016-The Arctic Council: 20 years of regional cooperation and policy-shaping. Akureyri: Northern Research Forum; 2016. p. 262-81.

169. Davidson AM. Regional governance without self-government: dynamism and change in the North American Arctic. In: Heininen L, Exner-Pirot H, Plouffe J, editors. Arctic Yearbook 
2015-Arctic governance and governing. Akureyri: Northern Research Forum; 2015. p. 68-85.

170. Kleist M. Greenland self-government and the Arctic. In: Berry DA, Bowles N, Jones H, editors. Governing the North American Arctic: sovereignty, security, and institutions. Basingstoke: Palgrave Macmillan; 2016. p. 247-52.

171. Powell RC. Institutions, resources, and the governance of postcolonial Greenland. In: Berry DA, Bowles N, Jones H, editors. Governing the North American Arctic: sovereignty, security, and institutions. Basingstoke: Palgrave Macmillan; 2016. p. 200-16.

172. Mortensen BOG, Barten U. The Greenland Self-Government Act: the pitfall for the Inuit in Greenland to remain an indigenous people? In: Alfredsson G, Koivurova T, Baker B, Kimmel M, editors. The yearbook of polar law, vol. 8. Leiden: Martinus Nijhoff Publishers; 2016. p. 103-28.

173. Jacobsen M. The power of collective identity narration: Greenland's way to a more autonomous foreign policy. In: Heininen L, Exner-Pirot H, Plouffe J, editors. Arctic Yearbook 2015-Arctic governance and governing. Akureyri: Northern Research Forum; 2015. p. 102-18.

174. Dingman EM. Greenlandic independence: the dilemma of natural resource extraction. In: Heininen L, Exner-Pirot H, Plouffe J, editors. Arctic Yearbook 2014-Human capital in the North. Akureyri: Northern Research Forum; 2014. p. 228-43.

175. Rodon T, Therrien A. Resource development \& land claim settlements in the Canadian Arctic: multilevel governance, subsidiarity and streamlining. In: Heininen L, Exner-Pirot H, Plouffe J, editors. Arctic Yearbook 2015-Arctic governance and governing. Akureyri: Northern Research Forum; 2015.

176. O'Faircheallaigh C, Ali S, editors. Earth matters-indigenous peoples, the extractive industry and corporate social responsibility. Abingdon: Routledge; 2017.

177. Wilson GN, Alcantara C. Mixing politics and business in the Canadian Arctic: inuit corporate governance in Nunavik and the Inuvialuit Settlement Region. Can J Polit Sci. 2012;45(4):781-804.

178. Nuttall N. Indigenous peoples, self-determination and the Arctic environment. In: Nuttall M, Callaghan TV, editors. The Arcticenvironment, people, policy. Amsterdam: Harwood Academic Publishers; 2000. p. 377-410.

179. Heininen L, Exner-Pirot H, Plouffe J. Arctic Yearbook 2012. Akureyri: Northern Research Forum; 2012.

180. Murray RW, Nuttall AD, editors. International relations and the Arctic - understanding policy and governance. Amherst: Cambria Press; 2014.

181. Gjørv GH, Bazely D, Marina G, Tanentzap A. Environmental and human security in the Arctic. London: Routledge; 2014.

182. Exner-Pirot H. Human security in the Arctic. The foundation of regional cooperation. Work Pap Arct Secur. 2012;2-11.

183. Kraska J. Arctic security in an age of climate change. Cambridge: Cambridge University Press; 2011.

184. Byers M. Crises and international cooperation: an Arctic case study. Int Rel. 2017;31(4):375-402.

185. Claes DH, Moe A. Arctic petroleum resources in a regional and global perspective. In: Tamnes R, Offerdal K, editors. Geopolitics and security in the Arctic: regional dynamics in a global world. Abingdon: Routledge; 2014. p. 97-120.

186. Fondahl G, Filippova V, Mack L. Indigenous peoples in the new Arctic. In: Evengård B, Larsen JN, Paasche Ø, editors. The new Arctic. Heidelberg: Springer; 2015. p. 7-22.

187. Stępień A, Koivurova T, Gremsperger A, Niemi H. Arctic indigenous peoples and the challenge of climate change. In: Tedsen E, Cavalieri S, Kraemer RA, editors. Arctic marine governanceopportunities for transatlantic cooperation. Heidelberg: Springer; 2014. p. 71-99.

188. Cochran PAL. Impacts on indigenous peoples from ecosystem changes in the Arctic Ocean. In: Berkman PA, Vylegzhanin AN, editors. Environmental security in the Arctic Ocean. Dordrecht: Springer Science+Business Media; 2013. p. 75-9.

189. Larsen JN. Global change, northern transformations, and a changing socio-economic landscape. In: Berkman PA, Vylegzhanin AN, editors. Environmental security in the Arctic Ocean. Dordrecht: Springer Science+Business Media; 2013. p. 219-29.

190. Barber DG, et al. Arctic sea ice. In: Snow, Water, Ice and Permafrost in the Arctic (SWIPA). Oslo: Arctic Monitoring and Assessment Programme (AMAP); 2017. p. 103-36.

191. Forbes BC. Arctic vegetation cover: patterns, processes and expected change. In: Evengård B, Larsen JN, Paasche $\varnothing$, editors. The new Arctic. Heidelberg: Springer; 2015. p. 117-32.

192. Sidorova L, Ferguson J, Vallikivi L. Signs of non-recognition: colonized linguistic landscapes and indigenous peoples in Chersky, Northeastern Siberia. In: Fondahl G, Wilson GN, editors. Northern sustainabilities: understanding and addressing change in the Circumpolar World. Heidelberg: Springer; 2017. p. 135-49.

193. Grenoble LA, Olsen Puju CC. Language and well-being in the Arctic: building indigenous language vitality and sustainability. In: Heininen L, Exner-Pirot H, Plouffe J, editors. Arctic Yearbook 2014 Human capital in the North. Akureyri: Northern Research Forum; 2014. p. 69-81.

194. Knyazeva E. Language rights for indigenous peoples: the case of the Russian Federation. In: Alfredsson G, Koivurova T, Stepien A, editors. The yearbook of polar law, vol. 5. Leiden: Martinus Nijhoff Publishers; 2013. p. 523-46.

195. Daveluy M, Lévesque F, Ferguson J. Humanizing security in the Arctic. Edmonton: CCI Press; 2011.

196. Shadian JM. Reimagining political space: the limits of Arctic indigenous self-determination in international governance? In: Keil K, Knecht S, editors. Governing Arctic change: global perspectives. Basingstoke: Palgrave Macmillan; 2017. p. 43-58.

197. Wilson GN, Kormos JJ. At the margins: political change and indigenous self-determination in postsoviet Chukotka. In: Heininen L, Exner-Pirot H, Plouffe J, editors. Arctic Yearbook 2015Arctic governance and governing. Akureyri: Northern Research Forum; 2015. p. 158-73.

198. Slowey G. Aboriginal self-determination and resource development activity: improving human security in the Canadian Arctic? In: Gjørv GH, Bazely D, Marina G, Tanentzap A, editors. Environmental security in the Arctic Ocean. London: Routledge; 2014. p. 187-202.

199. Latola K, Sarkki S, Stepien A, Jokinen M. Activities affecting land use in the European Arctic. In: Stepien A, Koivurova T, Kankaanpää P, editors. The changing arctic and the European Union. Leiden: Brill Nijhoff; 2015. p. 186-212.

200. Larsen JN, Huskey L. The Arctic economy in a global context. In: Evengård B, Larsen JN, Paasche Ø, editors. The new Arctic. Heidelberg: Springer; 2015. p. 159-74.

201. Battarbee K, Fossum JE. The Arctic contested. Brussels: Peter Lang; 2014.

202. Yakoleva N, Grover R. Crossing the land of indigenous people in the Arctic - comparison of Russian and North American experiences of economic growth and humans rights in energy and infrastructure projects. In: Pincus R, Ali SH, editors. Diplomacy on ice - energy and the environment in the Arctic and Antarctic. New Haven: Yale University Press; 2015. p. 198-212.

203. Nuttall M. Pipeline politics in Northwest Canada. In: Powell RC, Dodds K, editors. Polar geopolitics? Knowledges, Resources and Legal Regimes. Cheltenham: Edward Elgar; 2014. p. 277-94.

204. Sköld P. Perpetual adaptation? Challenges for the Sami and Reindeer husbandry in Sweden. In: Evengård B, Larsen JN, Paasche Ø, editors. The new Arctic. Heidelberg: Springer; 2015. p. 39-56. 
205. Sellheim N. The neglected tradition? - the genesis of the EU seal products trade ban and commercial sealing. Yearb Polar Law Online. 2013;5(1):417-50.

206. Cambou D. The impact of the ban on seal products on the rights of indigenous peoples: a European issue. In: Alfredsson G, Koivurova T, Stepien A, editors. The yearbook of polar law, vol. 5. Leiden: Brill Nijhoff; 2013. p. 389-416.

207. Heikkinen HI, Lépy É, Sarkki S, Komu T. Challenges in acquiring a social licence to mine in the globalising Arctic. Polar Rec. 2016;52(4):399-411.

208. Smits CCA, Justinussen JCS, Bertelsen RG. Human capital development and a social license to operate: examples from Arctic energy development in the Faroe Islands, Iceland and Greenland. Energy Res Soc Sci. 2016;16:122-31.

209. Wilson E. What is the social licence to operate? Local perceptions of oil and gas projects in Russia's Komi Republic and Sakhalin Island. Extr Ind Soc. 2016;3(1):73-81.

210. Wilson E, Stammler F. Beyond extractivism and alternative cosmologies: Arctic communities and extractive industries in uncertain times. Extr Ind Soc. 2016;3(1):1-8.

211. Koivurova T, et al. Social license to operate': a relevant term in northern European mining? Polar Geogr. 2015;38(3):194-227.

212. Riabova L, Didyk V. Social license to operate for mining companies in the Russian Arctic: two cases in the Murmansk region. In: Heininen L, Exner-Pirot H, Plouffe J, editors. Arctic Yearbook 2014 -Human capital in the North. Akureyri: Northern Research Forum; 2014. p. 527-37.

213. Prno J, Slocombe DS. A systems-based conceptual framework for assessing the determinants of a social license to operate in the mining industry. Environ Manag. 2014;53(3):672-89.

214. Prno J. An analysis of factors leading to the establishment of a social licence to operate in the mining industry. Res Policy. 2013;38(4):577-90.

215. Kimmel M. Sovereigns, not stakeholders: an Alaskan study in fate control. In: Alfredsson G, Koivurova T, Ágústsson HÓ, editors. The yearbook of polar law, vol. 6. Leiden: Martinus Nijhoff Publishers; 2014. p. 318-39.

216. Shadian JM. Arctic oil, Inuit resource governance, and the Arctic Council. In: Murray RW, Nuttall AD, editors. International relations and the Arctic - understanding policy and governance. Amherst: Cambria Press; 2014. p. 515-72.

217. Axworthy TS, Dean R. Changing the Arctic paradigm from cold war to cooperation: how Canada's indigenous leaders shaped the Arctic Council. Yearb Polar Law. 2013;5(1):7-43.

218. Tennberg M. Indigenous peoples as international political actors. A summary. Polar Rec. 2010;46(3):264-70.

219. Shadian JM. The politics of Arctic sovereignty: oil, ice, and Inuit governance. Abingdon: Routledge; 2014.

220. Pelaudeix C. Inuit governance in a changing environment: a scientific or a political project? In: Pelaudeix C, Faure A, Griffiths R, editors. What holds the Arctic together? Paris: L'Harmattan; 2012. p. 67-84.

221. Torrecuadrada García-Lozano S, Egea RMF. Environmental challenges for Arctic peoples. In: Conde E, Sánchez SI, editors. Global challenges in the Arctic region: sovereignty, environment and geopolitical balance. Abingdon: Routledge; 2017. p. 236-53.

222. Bratspies R. Using human rights to improve Arctic governance. In: Pincus R, Alo SH, editors. Diplomacy on ice - energy and the environment in the Arctic and Antarctic. New Haven: Yale University Press; 2015. p. 171-85.

223. Niemivuo M. Human and fundamental rights of the Sámi. In: Alfredsson G, Koivurova T, Jabour J, editors. The yearbook of polar law, vol. 7. Leiden: Martinus Nijhoff Publishers; 2015. p. 290-316.
224. Baker B. International law and the Arctic. In: Murray RW, Nuttall $\mathrm{AD}$, editors. International relations and the Arctic - understanding policy and governance. Amherst: Cambria Press; 2014. p. 483514.

225. Metallic N. Becoming a language warrior. In: Battiste M, editor. Living treaties - narrating Mi'kmaq treaty relations. Sydney: Cape Breton University Press; 2016.

226. Smylie J, Lofters A, Firestone M, O'Campo P. Population based data and community empowerment. In: O'Campo P, Dunn J, editors. Rethinking social epidemiology: towards a science of change. New York: Springer; 2011.

227. John TA. Nutemllaq Yugtun Qaneryararput: our very own way of speaking Yugtun in Alaska. In: Smakman D, Heinrich P, editors. Globalising sociolinguistics challenging and expanding theory. London: Routledge; 2015.

228. Schweitzer P, Gearheard S, Ivanova A, Stammler F, Ventsel A. Cultures and identities. In: Larsen JN, Fondahl G, editors. Arctic human development report-regional processes and global linkages. Copenhagen: Nordic Council of Ministers; 2015. p. 105-50.

229. Bartlett JG, Madariaga-Vignudo L, O'Neil JD, Kuhnlein HV. Identifying indigenous peoples for health research in a global context: a review of perspectives and challenges. Int J Circumpolar Health. 2007;66(4):287-307.

230. Kozlov A, Vershubsky G, Kozlova M. Indigenous peoples of northern Russia: anthropology and health. Int J Circumpolar Health. 2007;66(sup1):1-184.

231. Petrov AN, BurnSilver S, Stuart Chapin IIIF, Fondahl G, Graybill JK, Keil K, et al. Sustainability research - past, present, future, research in polar regions. London: Routledge; 2017.

232. Kristoffersen B, Langhelle O. Sustainable development as a global-Arctic matter: imaginaries and controversies. In: Keil K, Knecht S, editors. Governing Arctic change: global perspectives. Basingstoke: Palgrave Macmillan; 2017. p. 21-41.

233. Keil K. Sustainability understandings of Arctic shipping. In: Gad UP, Strandsbjerg J, editors. Politics of sustainability in the Arctic - Reconfiguring identity, time and space, studies in sustainability. London: Routledge; forthcoming 2018.

234. Fondahl G, Wilson GN. Northern sustainabilities: understanding and addressing change in the Circumpolar World. Heidelberg: Springer; 2017.

235. Bock N. Sustainable Development Considerations in the Arctic. In: Berkman PA, Vylegzhanin AN, editors. Environmental Security in the Arctic Ocean. Dordrecht: Springer Science+ Business Media; 2013. p. 37-57.

236. Larsen JN, Fondahl G. Arctic human development report-regional processes and global linkages. Copenhagen: Nordic Council of Ministers; 2015.

237. Larsen JN, Petrov A. Human development in the new Arctic. In: Evengård $\mathrm{B}$, Larsen $\mathrm{JN}$, Paasche $\varnothing$, editors. The new Arctic. Heidelberg: Springer; 2015. p. 133-46.

238. Bertelsen RG, Justinussen JCS. Knowledge and natural resources: a crucial connection for local benefits and sustainable Arctic development. In: Conde E, Sánchez SI, editors. Global challenges in the Arctic region: sovereignty, environment and geopolitical balance. Abingdon: Routledge; 2017. p. 281-305.

239. O'Garra T. Economic value of ecosystem services, minerals and oil in a melting Arctic: a preliminary assessment. Ecosyst Serv. 2017;24:180-6.

240. Young OR. The sustainability transition - governing coupled human/nature systems. In: Gjørv GN, Bazely D, Marina G, Tanentzap A, editors. Environmental and human security in the Arctic. London: Routledge; 2014. p. 83-97.

241. Halley P, Mercier ME. Sustainable development and the greening of sovereignty in the Canadian Arctic. In: Pelaudeix C, Faure A, Griffiths R, editors. What holds the Arctic together? Paris: L'Harmattan; 2012. p. 93-106. 
242. Humrich C. Sustainable development in Arctic international environmental cooperation and the governance of hydrocarbon-related activities. In: Pelaudeix C, Basse EM, editors. Governance of Arctic Offshore Oil and Gas. Abingdon: Edward Elgar; 2018. p. 31-46.

243. Hossain K, Koivurova T, Zojer G. Understanding risks associated with offshore hydrocarbon development. In: Tedsen E, Cavalieri S, Kraemer RA, editors. Arctic marine governance - opportunities for transatlantic cooperation. Heidelberg: Springer; 2014. p. 15978 .

244. Carothers C, Moerlein KJ. Total environment of change: impacts of climate change and social transitions on subsistence fisheries in Northwest Alaska. Ecol Soc. 2012;17(1):1-10.

245. Bell L. Economic insecurity as opportunity: job training and the Canadian diamond industry. In: Daveluy M, Lévesque F, Ferguson J, editors. Humanizing security in the Arctic. Edmonton: CCI Press; 2011. p. 283-94.

246. Kozlov A, Gutman S, Rytova E, Zaychenko I. Human and economic factors of long-distance commuting technology: analysis of Arctic practices. In: Goossens R, editor. Advances in social \& occupational ergonomics. Advances in Intelligent Systems and Computing. Heidelberg: Springer; 2017. p. 409-20.

247. Rouillard R. Foreign bodies in the Russian north: on the physiological and psychological adaptation of soviet settlers and 'oil nomads' to the oil-rich Arctic. In: Fondahl G, Wilson GN, editors. Northern sustainabilities: understanding and addressing change in the Circumpolar World. Heidelberg: Springer; 2017. p. 163-76.

248. Saxinger G. Lured by oil and gas: labour mobility, multi-locality and negotiating normality \& extreme in the Russian Far North. Extr Ind Soc. 2016;3(1):50-9.

249. Finnegan GF, Jacobs J. Canadian interprovincial employees in the Canadian Arctic: a case study in fly-in/fly-out employment metrics, 2004-2009. Polar Geogr. 2015;38(3):175-93.

250. Hendriksen K, Hoffmann B, Jørgensen U. Mineral exploitation and development in Greenland: engaging local workforce and planning flexible settlements. In: Heininen L, Exner-Pirot H, Plouffe J, editors. Arctic Yearbook 2014-Human capital in the North. Akureyri: Northern Research Forum; 2014. p. 257-72.

251. Dushkova D, Krasovskaya T, Evseev A. Environmental \& human impact of the Northern Sea Route \& industrial development in Russia's Arctic zone. In: Heininen L, Exner-Pirot H, Plouffe J, editors. Arctic yearbook 2017—change and innovation. 2017. p. $275-89$.

252. Stroeve JC, Serreze MC, Holland MM, Kay JE, Malanik J, Barrett AP. The Arctic's rapidly shrinking sea ice cover: a research synthesis. Clim Chang. 2012;110(3-4):1005-27.

253. Vihma T. Effects of Arctic Sea ice decline on weather and climate: a review. Surv Geophys. 2014;35(5):1175-214.

254. Francis JA, Vavrus SJ. Evidence linking Arctic amplification to extreme weather in mid-latitudes. Geophys Res Lett. 2012;39(6). https://doi.org/10.1029/2012GL051000.
255. Francis JA, Chan W, Leathers DJ, Miller JR, Veron DE. Winter northern hemisphere weather patterns remember summer Arctic Sea ice extent. Geophys Res Lett. 2009;36(7). https://doi.org/10. 1029/2009GL037274.

256. Keil K. The Arctic in a global energy picture: international determinants of Arctic oil and gas development. In: Keil K, Knecht S, editors. Governing Arctic change: global perspectives. Basingstoke: Palgrave Macmillan; 2017. p. 279-300.

257. Heininen L, editor. Future security of the global Arctic. Basingstoke: Palgrave Pivot; 2016.

258. Conde E, Sánchez SI, editors. Global challenges in the Arctic region-sovereignty, environment and geopolitical balance. Abingdon: Routledge; 2017

259. Tamnes R, Holtsmark SG. The geopolitics of the Arctic in historical perspective. In: Tamnes R, Offerdal K, editors. Geopolitics and security in the Arctic: regional dynamics in a global world. London: Routledge; 2014. p. 12-48.

260. Romaniuk SN. Global Arctic - sovereignty and the future of the North. Highclere: Berkshire Academic Press; 2013.

261. Keil K, Knecht S. Introduction: the Arctic as a globally embedded space. In: Keil K, Knecht S, editors. Governing Arctic change: global perspectives. Basingstoke: Palgrave Macmillan; 2017. p. $1-18$.

262. Knecht S, Keil K. Conclusion: governing the Arctic as a globally embedded space. In: Keil K, Knecht S, editors. Governing Arctic change: global perspectives. Basingstoke: Palgrave Macmillan; 2017. p. 301-10.

263. Albert M, Wehrmann D. Polarpolitik. Ein Bericht zur politikwissenschaftlichen Arktis- und Antarktisliteratur. Neue Polit Lit. 2015;60(1):63-89.

264. International Arctic Science Committee (IASC). Integrating Arctic research - a roadmap for the future, 3rd International Conference on Arctic Research Planning (ICARP III). 2015. p. 1-12.

265. Werner K, et al. Arctic in rapid transition: priorities for the future of marine and coastal research in the Arctic. Polar Sci. 2016;10(3): 364-73.

266. Bigras SC. Arctic Science in the common interest. In: Berkman PA, Vylegzhanin AN, editors. Environmental security in the Arctic Ocean. Dordrecht: Springer Science+Business Media; 2013. p. 313-22.

267. Gad UP, Strandsbjerg J, editors. The politics of sustainability in the Arctic - reconfiguring identity, time and space, studies in sustainability. Abingdon: Routledge; forthcoming 2018.

268. Koivurova T, Kankaanpää P, Stępień A. Innovative environmental protection: lessons from the Arctic. J Environ Law. 2015;27(2): 285-311.

269. Tai RTH, Pearre NS, Kao S-M. Analysis and potential alternatives for the disputed South China Sea from ocean governance in the polar regions. Coast Manag. 2015;43(6):609-27. 